\title{
Figueira da Foz as a "site of memory» on the escape route from occupied Europe during the Second World War (1943-1945). Proposal for a historical itinerary
}

\section{Figueira da Foz como «lugar de memoria» en la ruta de escape de la Europa ocupada durante la II Guerra Mundial (1943-1945). Propuesta de itinerario histórico}

\author{
Irene Vaquinhas \\ University of Coimbra, Portugal \\ irenemcv@fl.uc.pt \\ https://orcid.org/0000-0003-1889-165X
}

Recibido: 08/10/2020

Aceptado: 20/04/2021

Cómo citar este artículo: VAQUINHAS, Irene (2021). Figueira da Foz as a «site of memory» on the escape route from occupied Europe during the Seconf World War (1943-1945): Proposal for a historical itinerary. Pasado y Memoria. Revista de Historia Contemporánea, (23), pp. 362-383, https:// doi.org/10.14198/PASADO2021.23.15

\begin{abstract}
This study presents a proposal for a historical itinerary based on the «sites of memory» resulting from the presence in Figueira da Foz (a coastal city in central Portugal) of refugees from World War II. This seaside resort was one of the places chosen by the Salazar regime to receive refugees on a temporary basis, while they were waiting to embark to other countries or continents. Drawing on historical documentation, literary works and memoirs, this study identifies and maps out the places inhabited and frequented by these refugees during their stay in the city. The aim is to connect the intangible values of European history with the history of the city and its civic culture. By appreciating local heritage, it also seeks to maximize its potential to become a cultural-tourist product, enabling its integration into transnational cultural circuits,
\end{abstract}


within the framework of the European Union's policy for cross-border regions whose main aim was to free Europe from Nazi power and to break up of occupied Europe.

Keywords: Figueira da Foz (Portugal); Refugees; World War II; Cultural Tourism; Historical Itinerary.

\section{Resumen}

En este estudio se presenta una propuesta de itinerario histórico que toma como referencia «lugares de memoria» asociados a la presencia de refugiados de la II Guerra Mundial en Figueira da Foz, región central de Portugal. Este destino vacacional fue uno de los lugares escogidos por el régimen salazarista para acoger refugiados, mientras esperaban para embarcar rumbo a otros destinos. A partir de documentación histórica, se identifican los lugares donde vivieron, o que frecuentaron. El recorrido trazado al articular los valores intangibles de la historia europea con la historia de la ciudad, de la cultura cívica con la valorización del patrimonio local, tiene potencial para convertirse en un producto turístico-cultural. Asimismo, esa combinación permite integrarlo en circuitos culturales trasnacionales, en el marco de la política regional transfronteriza de la Unión Europea, que tenían como principal objetivo la liberación de Europa del dominio nazi y el escape de la Europa ocupada.

Palabras clave: Figueira da Foz (Portugal); Refugiados; II Guerra Mundial; Turismo cultural; Itinerario histórico.

Financiación: Research funded by Fundação para a Ciência e a Tecnologia (UIDB/00311/ 2020).

\section{Introduction}

In 1933, a new page of world history was launched with the rise of Nazi Germany and implementation of racially discriminatory regulations that would affect the lives of thousands of people, forcing them to abandon their families, homes, possessions and countries.

In the Spring of 1940, the Nazi occupation of countries in northern and western Europe, such as Denmark, Norway, Netherlands, Luxembourg, Belgium and France, provoked the mass flight of terrified populations, a phenomenon that intensified in the summer of 1942 with the start of the deportation of Jews (Mühlen, 2012: 59). The main exit route from the occupied territories was the Iberian one, which passed through the Pyrenees and across Spain to Lisbon, the Atlantic port of embarkation for other continents, particularly the United States (Pereira, 2017: 48). Portugal was, therefore, above all, a country of transit.

During the exodus from occupied France, visas granted by the Portuguese Consul in Bordeaux, Aristides de Sousa Mendes (1885-1954) (Andringa, 1996: 
8) in defiance of the Portuguese government and his immediate superiors, offered hope to Jewish and non-Jewish refugees alike that they might achieve the freedom they longed for (Pereira, 2017: 41-43).

For political and diplomatic reasons arising from the Anglo-Portuguese alliance, and in order to ensure neutrality in the conflict (Milgram, 2010: 99), the Salazar regime permitted these people to remain temporarily in the country as the political and social situation in Europe intensified, though there was a gradual tightening-up of restrictions as the migration flows swelled. Fearful of public order disturbances and the diffusion amongst the Portuguese population of subversive political ideas (particularly communism), the government imposed a policy of «dissuasion-repression», channelling the refugees to «fixed residence zones» outside the main urban centres, where they could be more easily controlled and supervised by the political police (Pimentel, 1996: 822-823).

The coastal city of Figueira da Foz, in the central region of the country, was one of the locations chosen for this purpose. It had been a popular summer resort since the end of the $19^{\text {th }}$ century, particularly after the establishment of the railway link with Spain in the 1880s, which brought an increased flux of holiday-makers from the border regions. During the Spanish Civil War (1936-1939), the city received people fleeing that conflict (Vaquinhas, 2015: 4757-4778); and in the 1940s, given its integration into the Iberian tourist routes and infrastructures characteristic of a summer bathing resort ${ }^{1}$, it became one of the official places for the accommodation of refugees fleeing countries of central Europe.

The aim of this study is precisely to recreate their presence in the city, identify the places most frequented by them or most representative of their stay, and propose a historic itinerary that will place the city of Figueira da Foz on the map of «sites of memory» on the European wartime escape route.

The working methodology involved the comparison of different types of sources, both handwritten and printed, belonging mostly to the Historical Archive of the Figueira da Foz City Council (A.H.M.F.F.), especially residence permits (1930-1945), Programas Visados (programmes certified) by the Inspecção dos Espectáculos (Inspectorate of Shows), a department of the censorship in Portugal Estado Novo (1939-1947), and the periodical press, amongst other documents. During the war, the local periodicals covered the

1. The other «zones of fixed residence» were also located in the central region of Portugal. Most of them (such as Curia, Luso, Caldas da Rainha and Foz do Arelho, Ericeira and Lousa de Cima) were seaside resorts or spas, with the material infrastructures able to cope with large contingents of people (Pereira, 2017: 59-63). 
subject regularly, such as the chronicle «Alô, Alô Bairro Novo» in the newspaper O Figueirense. At the time, the Bairro Novo (literally «new neighbourhood») was the epicentre of the social and recreational life of the town, becoming in the 1940 s a veritable Babel of different nationalities and tongues. These sources of information were compared with documents from the political police (Polícia de Vigilância e Defesa do Estado, hereafter PVDE), available in the Centre for Correspondence Received by the Figueira da Foz City Council, along with some memoirs and fictional works set in the Figueira beach resort.

How, then, should memorial tourism be defined and characterized? To what extent is it appropriate for the beach resort of Figueira da Foz, more used to being considered for a representative of sun and sea tourism? What values and priorities are defended by it? What advantages might it bring the city? These are some of the questions that this study seeks to answer.

\section{Memorial tourism and the preparation of historical itineraries}

The opening-up of European borders after the fall of the Berlin Wall in 1989 stimulated the development of a tourism of nostalgia and memory directed at sites of trauma, suffering, destruction or repression associated with the Second World War. Most of these were located, overwhelmingly, in Central and Eastern Europe.

But memorial tourism was not a completely new phenomenon; it dates back at least as far as the post-1st World War period when battlefields and monuments commemorating unknown soldiers fallen in combat became sites of pilgrimage (Jacquot; Chareyron et Cousin, 2018). It is a particular form of tourism that connects a powerful historical consciousness with the recovery of memorial testimony in which the "purely recreational aspects are relegated to second place» (Crahay, 2014: 151), in favour of a biographical relationship, individual or collective, on the part of the visitors with the places passed through (Bechtel; Jurgenson, 2013: 13).

These specific characteristics not only make problematic its categorization as a form of tourism, as some authors have pointed out (Bierwerth, 2011: 20; Crahay, 2014: 151), but also, in the line of Paul Ricoeur's psychoanalytic readings about the cult of memory (Ricoeur, 2000), have tended to associate it with a process of amamnesis. In accordance with this interpretation, it constitutes a cathartic and therapeutic journey «in search of one's roots», or indeed of «oneself», even purporting to provide reconciliation with the past and the reconstruction of an individual or collective identity (Bierwerth, 2011: 18-21; Besson, 2014; Cirac, 2014: 320; Jansen-Verbeke; George, 2015). Diaspora tourism is one of the names given to this tourism segment (Bierwerth, 
2011: 18), though it also has affinities with «dark tourism», a «morbid or macabre» tourism centred on places of conflict or spaces associated with death, oppression or suffering, such as the concentration camps (Knafou, 2012; Cirac, 2014: 320; Gonçalves, 2017: 29-34).

One of its fundaments lies in the ethical imperative of the duty to remember as a way of exorcizing a past that «is not forgotten» (Jansen-Verbeke; George, 2015). However, as the individuals directly involved in the traumatic events and their immediate descendants gradually disappear, the priorities and patterns of this type of tourism tend to change, becoming redefined on an individual (rather than collective, national, ethnic or cultural) scale (Besson, 2014).

At present, the instrumentalization by public powers of the concept of «duty of memory» seeks to confer utility and economic value upon the cultural patrimony of the past (Nora, 1999), putting it at the service of communities or places (Jacquot; Chareyron et Cousin, 2018). It is no longer only about using tourism as a motive for reconstructing destroyed places (Danchin, 2014), but of reintegrating the cultural and multi-ethnic dimension in a historically considered space and within its own development. It aims to restore a collective memory and confer pedagogical and use value upon the cultural heritage, conceiving it as a productive investment. These dimensions are framed by the current taste «for the past», the recognition of cultural heritage as a factor of sustainable development (Greffe, 2011: 928), and social and political concerns of the present time. That is the case with the notion of heritage as a «common good» of identity (Hertzog, 2011), as well as the ideological importance of values of reconciliation and tolerance, associated to peace, human rights and democracy, principles underlying the reconfiguration of European space after the end of the Second World War. With its complex character, memorial tourism seeks to provide the tourist or visitor with an enriching intercultural experience, allowing him or her to know the physical space of the events that occurred, and transmitting, in a didactic manner, educational values that encourage reflection about the historical context and the ideological questions that were at its source.

From these basic foundations, the range of products on offer in cultural tourism has increased, able to generate a wide range of activities. One of the most representative cases, for example are the thematic tourist routes about the liberation of Europe from Nazi control at the end of the Second World War. 
Without attempting to be exhaustive ${ }^{2}$, we should at least mention the Liberation Route Europe, a trail created by the Foundation of the same name, based in Netherlands, which includes a project co-financed by the European Union with the support of various international organizations and institutions: universities, former combatant associations, museums, tourist agencies and others (Brentjens; Lenders, 2028: 360). According to the institutional website, its purpose is «to bring together national perspectives on the liberation of Europe, to learn and share experiences and understanding, in order to create a unified awareness of the importance of freedom |... It deals with individual nation states' selective memories of the war, and calls for an international response, by seeking to examine the complex heritage of the Second World War from multiple historical perspectives. It connects this history with life in modern-day Europe, as well as other parts of the world, underscoring the role of international reconciliation and the promotion of reflection: reflection on the value of our hard-won freedoms $»^{3}$. The visits/routes proposed involve various «sites of memory» located in Belgium, the Czech Republic, France, Germany, Luxembourg, Italy, Poland and others. Portugal, however, is not included.

Strictly speaking, an itinerary, in this context, is a «description of a path $\mid$... specifying the places $|\ldots|$ and proposing a series of activities and services» (Maia; Baptista, 2011: 673), which obeys specific technical procedures and a structuring rationale (Figueira, 2013: 20).

In Portugal, there are very few urban historical itineraries related to the presence of refugees from the Second World War, although some local councils

2. There are numerous visits and tourist routes on the theme of the Second World War on offer in numerous European locations and available on the internet. See, for example, Visite historique à Vincennes: parcours autor de la seconde guerre mondiale (https://exploreparis.com/fr/1128-visite-historique-vincennes-parcours-autour-seconde-guerre-mondiale.html) or Randonneurs de mémoire, in various parts of Luxembourg. Regarding Spain, reference is made to the Caldas de Mallavella case, a small spa town in Girona province, which has accepted around one thousand Italian refugees, main theme of the work of Nadal Ferreras (2019) and Ordónez (sf). Some photos of jewish refugee children are display in United States Holocaust Memorial Museum, https://www.ushmm.org/search/ results/?q=caldas+de+malavella. Outside Europe, in the United States of America, reference is made to the Scattergood case, in the state of Iowa, which was a refuge for Europeans escaping from the holocaust, main theme of the PhD of Michael Luick-Thrams (1996), Out of Hitler's Reach: the Scattergood Hostel for European Refugees 1939-1943, https:// www.thegazette.com/news/80-years-ago-scattergood-took-in-refugees-fleeing-nazis/; "Out of Hitler's Reach», https://www.iowapbs.org/iowapathways/artifact/out-hitler's-reach

3. Similarly, the Fondation pour la Mémoire de la Shoah organizes visits to «sites of memory» related to the genocide of the Jewish people. http://www.fondationshoah.org/enseignement/voyages-pedagogiques (https://www.visitluxembourg.com/fr/tours-recommandes/ tour/t/randonneurs-de-memoire). 
and other state organizations promote initiatives or make available cultural facilities evoking the memory of the refugee in the $20^{\text {th }}$ century. This is the case of the Cascais Town Council, which in 1999 created the space Memory of Exiles $^{4}$, and the municipality of Almeida, which, in 2017 opened to the public the museum «Vilar Formoso Frontier of Peace. Memorial to the Refugees and the Consul Aristides de Sousa Mendes»; dedicated to the passage of refugees through Portugal during the Second World War, the museum is lodged in the Vilar Formoso railway station, one of Portugal's main land borders 5 .

As regards historical itineraries, one well-known case concerns the town of Ericeira, which was also a place of «fixed residence» (Júnior, 1998), its Tourist Board provides visitors with a printed route through various spaces and streets of the town where the refugees lived or passed. The leaflet identifies places to visit, accompanied by photographs: «Praça da República, the square where the refugees arrived $» ;$ «Panel of glazed tiles on Miguel Bombarda Street, the former Morais Pension where the first group of refugees was lodged»; «Building adapted into a Synagogue where the Jews could worship»; «Office of the Unitarian Service Committee in the Largo dos Condes in Ericeira which funded the refugees (in front of the post office)», «House in Florêncio Granate Street where Fritz Teppich lived between 1943 and 1946», amongst other information. This type of itinerary is thus a way of exploring the these places' relationship with the history of the Second World War, providing information about the refugees, their daily lives and activities, and the places they frequented.

\section{Figueira da Foz as safe haven: from «fugitives» to "guests»}

In the summer of 1940, the German occupation of France precipitated the flow of foreigners to Portugal, heading above all to Lisbon, the city with the only port of embarkation to the United States of America, and where could be found the various embassies, consuls, international aid organizations and transport operators (Lima; Neves, 2005: 21). Given the turn of events, the authorities

4. The main aim of the «Memory of Exiles Space», according to its website, is «to evoke the memory of one of the most important aspects of the county's history, namely its role as a place of refuge, hope and passage for thousands of exiles and refugees fleeing European conflicts - the Spanish Civil War and Second World War». https://www.cascais. pt/equipamento/espaco-memoria-dos-exilios. On this topic, see also Lima y Neves (2005).

5. Vilar Formoso Frontier of Peace. Memorial to the Refugees and to the Consul Aristides de Sousa Mendes. http://www.centerofportugal.com/pt/vilar-formoso-a-fronteira-da-paz/. This museum is organized into six exhibition spaces entitled: "People like us», "The nightmare begins», «The voyage», «Vilar Formoso - Frontier of Peace», «Through the lands of Portugal» and «Departure». For more on this museum, see also Ramalho (2014). 
decided to place the refugees in «fixed residences», following the example of other countries like France (Pimentel, 2006: 127-134).

The Figueira press recorded the arrivals of these hordes of refugees by train and by car. On 24th June, the first group arrived, having entered the country at Vilar Formoso on the Beira Alta railway line. The 85 refugees of various nationalities were distributed around «various hotels and pensions and some rented houses $»^{6}$. Then, at the beginning of July many more arrived ${ }^{7}$, making (according to the press) a total of around 600 individuals. The groups were received with «open demonstrations of kindness and sympathy so that they would not feel their situation too much». On their arrival at the Figueira railway station, a committee consisting of the vice-consul of France, members of the Municipal Tourist Board and the French community in the town («colónia francesa») was waiting to greet them, along with «dozens of people» ${ }^{8}$.

From «fugitives» («foragidos»), as they were sometimes called, the refugees rapidly became known as «guests» («hóspedes»), a linguistic shift that was registered in the local press, reflecting the frank hospitality with which they were received by most of the urban population ${ }^{9}$. Irene Flunser Pimentel in her work Judeus em Portugal durante a II Guerra Mundial ("Jews in Portugal during the Second World War») mentions the testimony of the Czech journalist, Eugen Tillinger, a refugee in the city, which seems to confirm the press story. Fearing that they would be incarcerated in a camp like those of the French, their fear evaporated when they arrived: «we have to thank the Portuguese with all our hearts. Their kindness has exceeded all limits (...) When we arrived, the city council had brought to the railway station everyone that knew French to receive us $|\ldots|$ the refugees from the war were received in a fantastic way $|\ldots|$ In the afternoon, the cinema allowed free entry $|\ldots|$ The menus in the restaurants were written in two languages $|\ldots|$ the council strictly forbade the hotels and businesses to charge us higher prices» (Pimentel, 2006: 131).

In fact, the press mentions the arrival in the city of the respected journalist, who contributed to Paris-Soir, and other papers ${ }^{10}$. His trajectory through Europe, as described by the local press - from Paris to Bordeaux, and from there, through Spain to Portugal - indicates that the journalist was one of

6. O Figueirense, 26th June 1940.

7. «Compreensão», O Figueirense, 3rd July 1940; «The refugees from the war found in Figueira the peace and quiet they so desired», O Figueirense, $9^{\text {th }}$ July 1940; O Figueirense, $27^{\text {th }}$ July 1940.

8. «Refugiados», O Figueirense, 29th June 1940.

9. «Compreensão», O Figueirense, 3rd July 1940.

10. «The refugees from the war find in Figueira the peace and quiet they so desire», $O$ Figueirense, $9^{\text {th }}$ July 1940. 
those that benefitted from the visas granted by the consul Aristides de Sousa Mendes ${ }^{11}$. He was not, however, the only one: there were many others.

The analysis of a cluster of visas (104 in number) contained, for unknown reasons, in the Figueira da Foz Municipal Archive, shows the diversity of nationalities present in the city in 1944. Most were born in Spain (43), followed by France (23), Belgium (14) and Brazil (13) (Table I).

Table I. Breakdown of nationalities based on residence permits (1944)

\begin{tabular}{|l|c|c|c|}
\hline & SF & SM & TOTAL \\
\hline Germany & 1 & & 1 \\
\hline Belgium & 7 & 7 & 14 \\
\hline Brazil & 3 & 10 & 13 \\
\hline Czechoslovakia & 1 & & 1 \\
\hline Spain & 20 & 23 & 43 \\
\hline France & 12 & 11 & 23 \\
\hline Italy & 2 & 2 & 4 \\
\hline Switzerland & 1 & & 1 \\
\hline China & & 2 & 2 \\
\hline Netherlands & & 1 & 1 \\
\hline Poland & & 1 & 1 \\
\hline TOTAL & 47 & 57 & 104 \\
\hline
\end{tabular}

Source: A.H.M.F.F, Residence permits issued to foreigners

As for the date of entry into Portugal, over half $(59.6 \%, 62$ cases) of the foreigners came in 1940 or afterwards, while $36.5 \%$ (38 cases) entered between 1933 and 1939. In 4 cases (3.8\%) there is no information in this respect.

\subsection{The impact of the refugees: transformations of daily life}

The passage of refugees through the city is mentioned in some memoirs. Luís Cajão in his book As torrentes da memória. Histórias e inconfidências do arcoda-velha («The torrents of memory: Stories and secrets from the olden days») describes how some hundreds of refugees flooded into the city «fleeing Hitler and Holocaust» (Cajão, 1979: 13), which affected the peaceful lifestyle of the town and imprinted new habits, exerting a stimulant effect on the local society. Many, says Leitão Fernandes, «were able $|. .$.$| to find the welcoming atmosphere$ that was needed»; the cafés of the Bairro Novo became busy «the whole year 
round», something that was not usual at that time ${ }^{12}$. That is to say, the «foreign infiltration», as Augusto Veiga called it, animated the Bairro Novo, extending the «summer season into the autumn» ${ }^{13}$.

In the city, the foreigners encountered warm hospitality and little risk, and were charmed by the sunshine and the light. The atmosphere was relaxed, and life ran along smoothly. In wartime, the city was seething with people: «along the main thoroughfares, in the parks, in the avenues, in cafés, on benches, there was a constant vibration of foreign tongues, with Poles, Belgians, Czechs, Dutch and French, of both sexes, lending a note of cosmopolitanism to the city ${ }^{14}$. The writer Miguel Viqueira portrayed the beach of Figueira during this period in a novel, which he eloquently entitled Praiabela («Beautiful beach») (1994).

The transformations of daily life were often mentioned in the press: French was replacing Spanish and Portuguese; there were more houses and rooms to rent, with advertisements in various languages; films were subtitled in French ${ }^{15}$; the bathers spoke French... There was, however, one detail that aroused numerous comments: female clothing and habits, in particular, the use of trousers and smoking. In fact, some newspapers recommended trips to Figueira da Foz just so that their Portuguese readers could «come into contact with 20th century civilization»: this because they would «have occasion to see ladies in trousers and without them, smoking like agents of the guarda fiscal that kept watch over the river banks and sea coasts» ${ }^{16}$.

A significant number of refugees belonged to «the liberal middle-classes», including writers, painters, sculptures, people from the performing arts, musicians, liberal professionals, businessmen, including jewellers. From the outset, the Grand Casino Peninsular offered free entry to matinées ${ }^{17}$. With this unexpected supply of cultural labour, the other venues recruited their services, managing to get around labour provisions affecting foreigners by associating them to charity events, whose beneficiaries could be local institutions or the

12. Leitão Fernandes, «Short history of the Figueira Casino», A Voz da Figueira, 7th December 1972.

13. O Figueirense, 9 th October 1940.

14. «The refugees from the war find in Figueira the peace and quiet they so desire», $O$ Figueirense, 9th July 1940.

15. These alterations may be accompanied through the programmes of the concert halls in Figueira da Foz, from July 1940, many of which are available in the Municipal Archive, in the City Council boxes. Tourism. Certified Programmes. Inspectorate of Shows (Câmara Municipal. Turismo. Programas Visados (Inspecção dos Espectáculos).

16. O Figueirense, 20th July 1940.

17. Jornal-Reclamo, n. ${ }^{\circ} 234$, 13th July 1940. 
refugees themselves. Some performed in shows, while others held art exhibitions or gave talks, amongst other initiatives.

This was the case with the couple, Colette Gaveau (1913-1987) and Witold Malcuzynski (1914-1977), both pianists, who had scarcely arrived in 1940 («in great destitution», as Luís Cajão informs us) before they were invited to perform at the Casino on $17^{\text {th }}$ July 1940 in a charity show ${ }^{18}$. Polish by birth and a disciple of the composer Padereswsky, Witold Malcuzynski, a great performer of Chopin, was considered one of the «last Romantic pianists». He and his wife arrived in Figueira da Foz armed with visas issued by Sousa Mendes, according to the Aristides Foundation website. In that same month, the casino itself organized another event in his homage, in which he himself was the beneficiary.

As Luís Cajão explains in his memoirs, on 30th July 1940, the managers of the Casino, Arménio Faria and Ernesto Tomé, «organized a concert |...| that yielded six thousand escudos - a reasonable amount for that season». He goes on: «Hardly had Witold Malcuzynski received this amount when he grabbed us by the arm - his wife and me - and ushered us into the gaming room. Having exchanged the money for tokens, he divided them up amongst the three of us and asked each of us to occupy a roulette table. |... A quarter of an hour later, both of them had lost everything. I, however, had gone back to the guichet and exchanged the tokens back into money $|. .$.$| , which I only gave back to them$ when I left them at the door of their hotel» (Cajão, 1979: 13).

Some years after the end of the Second World War, in 1948, the «artistic genius» returned to Figueira da Foz to do a piano recital in the Grand Salon of the Casino Peninsular, as a sign of his «gratitude for the attention and kindness that surrounded him and his compatriots at their hour of need $»^{19}$. Still today the Figueira casino bears a plaque on the wall of its present gaming room commemorating that concert given by the refugee couple.

References to artists do not stop here. There was the French film actor, Marcel Dalio (1899-1983) ${ }^{20}$; the writer, Gisèle Quittner Allatini (1883-1965), also of French origin, who gave various talks at the Casino and wrote some chronicles for the local press ${ }^{21}$; and the Czech painter, Ivan Sors (1895-

18. A.H.M.F.F. Town Council. Tourism. Certified Programmes. Inspectorate of Shows. 1940. 19. Programme of 28th June 1948. A.H.M.F.F. City Council. Tourism. Certified Programmes. Inspectorate of Shows. 1948.

20. On 7 th August 1940, the film «Maltese House», with the artist Marcel Dalio («the great French film actor who is now in Figueira da Foz») was shown at the Grand Casino Peninsular of Figueira da Foz. City Council. Tourism. Certified Programmes. Inspectorate of Shows. 1940.

21. «At the Casino», Jornal-Reclamo, No. 246, 5th October 1940; No. 247 of 12th October 1940 and No. 252 of 16th November 1940. As a freelance journalist, she wrote a 
1950), the main character of Afonso Cruz's literary fiction, O pintor debaixo do lava-louça («The painter beneath the sink», 2013) who, in August 1940, exhibited some of his paintings and drawings in the casino (some of which show fishermen from Buarcos, a fishing village near the beach of Figueira da Foz). Several of these pictures, along with others by other refugees, are now at the Santos Rocha Municipal Museum in the city ${ }^{22}$. In Afonso Cruz's fictional work, Josef Sors resides in the house of a well-known photographer from the city, a relative of the novelist, sleeping in a corner of the house. The book reads: «Under the sink there was a relatively large space, which stretched beneath the stove. A mattress was laid out there and it was there that Sors would sleep, hidden behind the firewood, for fear that the agents of the PVDE would appear in the middle of the night» (Cruz, 2013: 136).

The number of restaurants in the city increased and the streets were lively, particularly in the Bairro Novo, where the various orchestras that played in the cafes, casinos and restaurants, would try to outdo each other, sometimes accompanied by international artistes that the war had brought to the city and who would do the rounds of the various venues.

The «Café Nicola» attracted a host of people with its high-spirited jazz orchestra («Orquestra Ginásio Jazz») and above all, with the solos of violinist David Teller, a Russian refugee, accompanied on the piano by Engleman Malanzer ${ }^{23}$, another refugee, and by the trumpet of Joaquim Machado. In the Café Espanhol, you could hear the «Portuguese Orchestra» from the city of Porto; while in the Ocean Casino, which was more upmarket, it was possible to dine to the sound of the orchestras while watching a variety show. Finally,

chronicle «Figueira da Foz» in Jornal-Reclamo, No. 262, 25th January 1941. She also wrote a letter to Aristides de Sousa Mendes, thanking him for the help he had given her in Bordeaux, in which she states: «I am making a point of writing to you to tell you of the profound admiration there is for you in all the countries where you have worked as a consul. You are for Portugal the best form of propaganda, and an honour to your country. Everyone that has known you praises your courage, great heart and chivalrous spirit, and they add: if the Portuguese are all like General Consul Mendes, they are a nation of gentlemen and heroes». AHD - Disciplinary Proceedings of Aristides de Sousa Mendes. Accessed on 8th May 2018. http://vidaspoupadas.idiplomatico.pt/ aristides-de-sousa-mendes/documentos/

22. "Exhibition of paintings and drawings», Jornal-Reclamo, No. 240, 20th August 1940; «Ivan Sors», Jornal-Reclamo, No. 240, $16^{\text {th }}$ November 1940. The museum also holds some pictures by the Polish painter, Wanda Ostrowsk. I would like to thank Ana Paula Cardoso, from the Figueira da Foz City Council, for this information.

23. In 1946, after the war had already ended, the violinist David Teller continued in Figueira da Foz. His name is mentioned on posters of musical events, at least on the $22^{\text {nd }}$ of June 1946. A.H.M.F.F City Council. Tourism. Certified Programmes. Inspectorate of Shows. 1946. 
in the most recent venue to open in the Bairro Novo, the seafood bar known as the «Lagosta Vermelha» («Red Lobster»), one of the most luxurious and fashionable in Figueira», Classical Spanish dances were performed. «Up to a point,», says Luís Cajão, «my city was a bohemian city $|. .|$.$» , recreating in a$ way the atmosphere of the 1920s.

Gambling, particularly roulette, also reflected the importance of the refugees. Many of them were «well-heeled folk that would gamble without concerns», and many of them had the habit of going to the Casino, («casino-ing», as they would say at the time), contributing to its takings. The profits from gambling, which prove the impact of the foreign refugees on the city, particularly after 1942, were placed at the service of the Council welfare policy until the year 1947, when the Sociedade Figueira-Praia (Figueira-Beach Company) took over the casino (Vaquinhas, 2012: 224-228).

However, the presence of the refugees did raise some problems for the local authorities, particularly as regards their supervision, as it was not clear what they were or were not permitted to do. This resulted in frequent requests for clarification from the political police. The nearest headquarters of the PVDE was some $50 \mathrm{kms}$ away in Coimbra, which meant that there were no agents in Figueira da Foz. Hence, the job of overseeing the refugees fell to the Council staff. This helps explain the rather relaxed atmosphere experienced by the foreigners in the city ${ }^{24}$.

The correspondence between the PVDE and the Figueira authorities reveals some of the restrictions that the refugees were subjected to, allowing us a glimpse of their daily lives. They were strictly forbidden from «using cameras or other means, such as painting or drawing, to fix points that could be considered of strategic interest on our coastal area or land border $»^{25}$.

As regards their accommodation, whatever kind it was, the owner was obliged, within 48 hours, to communicate the presence of any foreigner, even if the stay was only for one night, on pain of a fine. "In order to intensify the inspection of foreigners' residences», they were obliged to send, at the beginning of each week, a report of all foreigners lodged in hotels, pensions or guest houses ${ }^{26}$. Similarly, visits from foreigners to refugees resident in Figueira

24. The costs of installing PVDE agents in the city (food and accommodation at least) was studied by the local authorities, as is clear from PVDE documentation, but was hotly contested by the mayor. The dispute can be followed in the correspondence exchanged between the two institutions.

25. A.H.M.F.F, Folder PVDE, undated. (Confidential circular).

26. Montemor-o-Velho Historical Archive, Confidential Circular from the PVDE of 11th November 1943, Folder Documents relating to the PVDE and PIDE (1937-1975). 
had to be immediately communicated by the owner of the residence on pain of a fine. Foreigners that were resident in the country could be allowed to leave on Saturdays without having to present themselves each time they returned ${ }^{27}$.

These were the rules, which did not mean that they were completely complied with. Although the foreigners were forbidden to go more than $3 \mathrm{kms}$ out of the city, there are references of trips to Alhadas ${ }^{28}$ (a town in the county of Figueira da Foz) and Curia (some $64 \mathrm{kms}$ away), another site of «fixed residence», used particularly for weddings. The author Luís Cajão mentioned above, who was a young man in the 1940s and member of the «Refugees' Reception Committee» of Figueira da Foz, describes some of the excursions made, including to a wedding in $\mathrm{Curia}^{29}$. He also describes his wonder at the beauty of the Polish woman, Irene Kisterówna who «ate fish with sugar syrup» and told him that «that the nicest name she knew in Portuguese was 'alguidar' ['bowl'] and that this would be the name of her first son» (Cajão, 1979: 15). Some refugee children were also enrolled in the education system, more precisely in the Academia Figueirense, as was the case of Edith Liliane Schwarz ${ }^{30}$, whose family, according to the Aristides Sousa Mendes Foundation, had also been issued visas by that consul in Bordeaux.

All that benefitted from Figueira's hospitality were very grateful for it, as can be seen by the letters of thanks deposited in the city's historical archive, addressed to the president of the Council of Ministers ${ }^{31}$, Oliveira Salazar, and to the Mayor of the city - at the time the lawyer Rui Manuel Nogueira Ramos (1901-1987) - which refers expressly to the «warm welcome» and «kindness of the local population and council staff $»^{32}$.

27. A.H.M.F.F, PVDE Folder, 5th August 1944.

28. In this town, in November 1940, at the civil registry office, Maurice Maucki Maotti, a civil engineer from Oran (Algeria) married Marcelle Gersslik Kalick, journalist from Warsaw (Poland), Jornal-Reclamo, No. 253, 23 ${ }^{\text {rd }}$ November 1940. According to the Aristides Sousa Mendes Foundation, he had come into Portugal with a visa issued by the consul Aristides Sousa Mendes.

29. This had probably been the wedding of Grzegorz Fitelberg (Polish composer and violinist) to Zofia Helene Reicher, at Curia, in the summer of 1940. http://sousamendesfoundation.org/portugal/figueira-da-foz (accessed 13th May 2018).

30. A.H.M.F.F, Academia Figueirense, Matriculation Book, No. 12, 1940-1941, Entry No. 25, 7th October 1940.

31. O Figueirense, 13th and 17th July 1940.

32. The letter is written in French and sent from Caldas da Rainha, dated $29^{\text {th }}$ November 1941, and its 14 signatories present themselves in the following way: «We, the last of the refugees, who received in Figueira da Foz such a warm welcome, according to the ancient traditions of Portuguese hospitality, famous throughout the world, wish to express our most heartfelt thanks to you, Your Excellency, and to all the employees of the town and its population, as we depart. We all hope that God will bless your 


\section{Proposed itinerary: in the footsteps of the refugees of the Second World War}

On the basis of the historical contextualization of the presence of foreign refugees in the city at the time of the Second World War, a route is hereby proposed that will take in some of the places frequented or mentioned in the referenced works, considered to be being essential visiting points on a continuous route running from the city's railway station ${ }^{33}$.

\subsection{The railway station}

Inaugurated in 1882, the railway station was, for many refugees, their first contact with the city, especially for those that had taken the Iberian route across Spain, entering in Vilar Formoso, and then travelling to Figueira da Foz on the Beira Alta line. At the station, they were met by the city's «Refugee Reception Committee», which consisted of the city's vice-consul of France, members of the Municipal Tourist Board and the «French colony». The writer Luís Cajão, a young man who spoke French well, was part of the Committee, as he mentions in his work As torrentes da memória.

\subsection{Council House on Saraiva de Carvalho Avenue}

Designed by the Italian architects Cesare Ianz and Giuseppe Florentini, and with interior decoration by Ernesto Korrodi, the Council House was inaugurated in 1897. This building housed most of the Council's administrative departments. The refugees were overseen by the council staff with the support of the political police (PVDE), based in Coimbra. In the building, the refugees would also advertise their services, such as «giving French, English and German lessons» ${ }^{34}$.

town and allow it to blossom and have a great future. Please accept, Your Excellency, this expression of our highest consideration». Amongst the signatories whose names can be deciphered are those of Ester Mandelm; Maria Graulard; Edith Liane Schwarz; Erna Schwarz; Gertruda Kauitzoós; Haleine Kravowiek and Rachel Moed. A.H.M.F.F. Figueira da Foz Municipal Council. Correspondence Received. 1941. Miscellaneous Unnumbered bundle.

33. This expedition might sometimes be extended to the towns of Alhadas (county of Figueira da Foz) and Curia (county of Anadia and district of Aveiro), outside the urban perimeter of Figueira da Foz.

34. Jornal-Reclamo, No. 234, 13th July 1940. 
4.3. The Bairro Novo, epicentre of the temporary residence and social and recreational heart of the city

When Figueira da Foz became a bathing resort in the third quarter of the 19th century, it became necessary to physically enlarge the city and build accommodation to house the large influx of foreign visitors. The new neighbourbood of Santa Catarina was born, with infrastructures designed for the summer season (hotels, pensions, restaurants, casinos). A qualitative leap was taken in 1884, with the construction of the Saraiva de Carvalho Theatre-Circus, converted into a casino in 1895, under the name Casino Peninsular da Figueira da Foz (Vaquinhas, 2011: 115-141). In the 1940s, the Bairro Novo was a dynamic centre of social life and recreation, and it was here that many of the refugees lived (in hotels, pensions, and rented rooms and houses). There are frequent references in the press and other works from the time to the multilingual babble that could be heard in its streets. The French writer Gisèle Quittner Allatini refers, in a chronicle of the Jornal-Reclamo da Mais linda Praia de Portugal to the presence of Aristides Sousa Mendes in the streets of the neighbourhood in the summer of 1940, and how the foreigners would «stop him at every step in order to shake his hand and thank him $»^{35}$.

\subsubsection{The «Havana House» and the «Municipal Tourist Board» in Cândido dos Reis Street}

Located in the heart of the Bairro Novo, the Casa Havanesa ( Havana House»), bookshop and photographic studio, founded in 1885 (Cascão, 2017), was an important support space for the refugees. Owned by José and Manuel Santos Alves, it housed the headquarters of the vice-consulates of Belgium and England, positions held by the two brothers respectively. They supported many refugees, and as a result, were decorated, after the War by the Belgian and British governments for the services they provided to freedom. They had an office which provided information for the refugees. In the same street was the Municipal Tourist Board, a place often mentioned in the press as the «House of the Refugees in Figueira da Foz», which offered «postal, telegraph and telephone services uninterruptedly from the morning to midnight, and which would also provide them with information. It was this building that the refugees adopted as their home», wrote one refugee, called Boleslaw Biclski ${ }^{36}$.

35. «Figueira da Foz», Jornal-Reclamo, No. 262, 25th January 1941.

36. Boleslaw Biclski, «Honourable appreciations», Jornal-Reclamo, No. 267, 1st March 1941. 
Afonso Cruz sets one of the episodes in his book in a commercial store which corresponds to the Casa Havanesa. The story reads: «Mr Costa had a photography shop in the street, whose garden led to the Casino Peninsular $|. .$. Josef Sors entered the shop out of breath |... The woman, D. Rosa, who was behind the counter, near the window, spotted a PVDE agent approaching at a run. She made a sign to her husband, and he ordered Sora to hide behind the counter. Agent Teixeira came in |...| «Where's the Jew?» «What Jew?» asked the photographer $|. .$.$| «This isn't the Jew I was after. Where's the other one?»$ Mr Costa turned his pockets inside out and said: «I only attend one Jew at a time. Now it's this one. Come by at another time and you'll find another $|\ldots|$ » (Cruz, 2011: 127-128).

\subsubsection{The Grand Casino Peninsular of Figueira da Foz}

In the 1940s, the Grand Casino Peninsular (so-called because of the concession granted to it after gambling was made legal in 1927) was seething with people and underwent great development, largely due to the presence of refugees, but also because of the tungsten trade that had developed in the context of the war (Vaquinhas, 2012: 224-228). The presence of the refugees in the casino is very well documented, as mentioned above, and today, one of the walls of the present gaming room bears various commemorative plaques of spectacles held there. We should recall that many refugees were internationally renowned artists. This fact is also mentioned in works about the era, such as Luís Cajão's book Um secreto entardecer. Tempos. Lugares. Alguns epitáfios, which describes how Witold Malcuzynski returned to Figueira da Foz to do a recital in the casino, in order to express his gratitude for the way he had been received in wartime (1998: 44-47).

\section{Conclusion}

Memorial tourism represents a market niche with enormous economic and cultural potential. In Figueira da Foz, an itinerary on the theme of the Second World War could complement the cultural provision provided by the official organizations and showcase the city's historical heritage ${ }^{37}$. This study has aimed

37. This is the case, amongst others of the itinerary Art Nouveau in the Streets of the Bairro Novo, an initiative of the Dr. Joaquim de Carvalho Secondary School in the city of Figueira da Foz. The Council's cultural department has organised some activities on this subject, particularly exhibitions on the subject, but only on an occasional basis. The creation of a visitors' centre on the subject of the wars experienced by the city is a more complex proposal. 
primarily to map out the historical data related to the theme and propose a route that would be historically sustained.

The proposal also aims to present the city through the eyes of people that resided there temporarily while they waited for the moment when they could depart to other locations. In the urban setting, the refugees were able to enjoy some degree of freedom, as they were received largely with sympathy and understanding by the local authorities and population. Today, Figueira da Foz may continue to benefit from that singular moment in its history, by investing in the reconstitution of routes and itineraries trodden by the refugees in the city, as well as the collection of oral testimony from people that experienced the events at first hand or who had heard them told, contributing to preservation of its collective memory (since history, literature and memory are mutually complementary).

The proposed route will have a strong international dimension, potentially attracting public from various countries. It could also form part of international circuits, such as the Libération Route Europe, as well as complementing other tourist routes offered by other organizations in the city. It could be managed by tourist companies or others. At national level, links could be forged with other towns which, like Figueira da Foz, were «zones of fixed residence» for refugees.

The subject of refuge (and we should not forget that Figueira da Foz also offered shelter to refugees from the Spanish Civil War) is a sensitive topic, but it projects the image of an open, tolerant and cosmopolitan city ${ }^{38}$.

As one of the Council reports of 1940 states: «The arrival in Figueira of large numbers of foreign refugees may be of propaganda value for us in the future, hopefully bearing fruit of the best kind $»^{39}$. I believe that the time has now arrived to make use of those fruits, announced back in $1940 \ldots$

\section{Manuscript sources}

Arquivo Histórico Municipal da Figueira da Foz (A.H.M.F.F)

Academia Figueirense, Livro de Matrículas n. ${ }^{\circ}$ 12, 1940-1941.

Câmara Municipal. Secção Policial. Serviços de Estrangeiros. 1 cx. 1930-1945.

38. The creation of a tourist route, in the town, linked to the Spanish Civil War refugees presence as well as its potential interconnection with the one mentioned in this article, was the object of study by I. Vaquinhas, named "Spanish Civil War Memories in the Figueira da Foz beach (1936-1939): historical itinerary proposal», currently under publication.

39. A.H.M.F.F. Figueira da Foz Municipal Council. Management Reports. Revenue and Expense Budgets. Activity Plans. 1940. 
Câmara Municipal. Correspondência Recebida. 1939, Maço n. ${ }^{\circ} 2574$ - Governo Civil de Coimbra.

Câmara Municipal. Turismo. Programas Visados (Inspecção dos Espectáculos). Pastas: Jan-Dez 1942; Jan-Dez 1943; Julho-Dez 1946; Jan-Junho 1947; JulhoDez 1947; Julho-Dezembro 1948.

Correspondência recebida da PVDE relativa à emissão/envio de títulos de residência de estrangeiros, 1944, 1 pt.

Câmara Municipal da Figueira da Foz. Correspondência Recebida. 1. Diversa. 1951.

Câmara Municipal. Turismo. Programas Visados. Inspecção dos Espectáculos. 1940; 1946 e 1948.

Arquivo Histórico Municipal de Montemor-o-Velho

Pasta Documentos relativos à PVDE e PIDE (1937-1975).

\section{Printed Sources and Bibliography}

ANDRINGA, D. (1996). Abranches, Aristides de Sousa Mendes do Amaral. In F. DE ROSAS and J.M.B. BRITO (dirs.). Dicionário de história do Estado Novo. Vol. I: A-L (8). Venda Nova: Bertrand Editora.

BECHTEL, D.; JURGENSON, L. (dir.) (2013). Le tourisme mémoriel en Europe centrale et orientale. Paris: Éditions Pétra.

BENEY, A.; MASSY, B.; LOEFFEL, B; GASS, C. (2014). Étude de cas. Le tourisme macabre. Available in: apps.hevs.ch/blog/getfilesFTO.aspx?id=434

BESSON, Rémy (2014). Delphine Bechtel et Luba Jurgenson (dir.), Le tourisme mémoriel en Europe centrale et orientale, Lectures [En ligne], Les comptes rendus, 2014, mis en ligne le 18 mars 2014, consulté le 23 juillet 2019. https:// doi.org/10.4000/lectures. 13980

BIERWERTH, G. (2011). Tourisme de mal du pays: revisiter et ré-habiter les lieux d'origine. Département d'Histoire. Faculté des Lettres. Université Laval. Québec (mémore de maîtrise). Available in: https://corpus.ulaval.ca/jspui/bitstream/20.500.../1/28859.pdf

BRENTJENS, J.; LENDERS, W. (2028). The Liberation Route Europe: Challenges of Exhibiting Multinational Perspectives. In H. BAK, F. MEHRING, M. ROZA and S. LEVIE (eds.). Politics and Cultures of Liberation: Media, Memory, and Projections of Democracy (360-372). Leiden: Brill. https://doi. org/10.1163/9789004292017_019

CAJÃO, L. (1979). As torrentes da memória. Histórias e inconfidências do arco-davelha. Lisboa: Palas Editores.

CAJÃO, Luís (1998). Um secreto entardecer. Tempos. Lugares. Alguns epitáfios, Lisboa, Editorial Escritor / 10 anos. 
Caldas de Malavella. Available in: https://www.ushmm.org/search/results/ $? \mathrm{q}=$ caldas + de + malavella

CASCÃO, R. (2017). Casa Havanesa: um estabelecimento comercial ao serviço da cultura. In Casa Havanesa: o encerrar de um ciclo. Figueira da Foz: Câmara Municipal da Figueira da Foz, Divisão de Cultura, Museu, Biblioteca e Arquivos.

CIRAC, S. (2014). Delphine Bechtel et Luba Jurgenson (dir.), Le tourisme mémoriel en Europe centrale et orientale, Paris, Éditions Petra, col. Usages de la mémoire. Revue d'études comparatives Est-Ouest, 45(3), 319-325. https://doi.org/10.4074/ S0338059914003143

CRAHAY, F. (2014). Turisme mémoriel. Témoigner. Entre histoire et mémoire. Revue pluridiscilinaire de la Foundation Auschwitz, 117, 151-152. consulté le 23 juillet 2019. https://doi.org/10.4000/temoigner. 1215

CRUZ, A. (2013). O pintor debaixo do laiva-loiças. 2. ${ }^{a}$ edição. Lisboa: Editorial Caminho SA.

DANCHIN, E. (2014). Le temps des ruines, 1914-1921. Rennes: Presses Universitaires de Rennes. https://doi.org/10.4000/books.pur.92740

Espaço Memória dos Exílios. Available in: https://www.cascais.pt/equipamento/ espaco-memoria-dos-exilios.

FIGUEIRA, L. (2013). Manual para elaboração de roteiros de turismo cultural. Tomar: Instituto Politécnico de Tomar.

Figueirense (O), 1936-1941.

Fondation pour la Mémoire de la Shoah. Available in: http://www.fondationshoah. org/enseignement/voyages-pedagogiques.

GONÇALVES, A. F. S. (2017). Dark Tourism. O lado sombrio do turismo: aplicação à cidade do Porto. Porto: Instituto Superior de Contabilidade e Administração do Porto. Instituto Politécnico do Porto (Dissertação de Mestrado). Available in: http://hdl.handle.net/10400.22/10949.

GREFFE, X. (2011). L'économie politique du patrimoine. De la médaille au rhizome. In Le patrimoine, moteur de développemnt. Heritage, a driver of development, Actes du Symposium de la XVII ${ }^{\text {ème }}$ Assemblée Génerale de l'ICOMOS / Proceedings of the Icomos general Assembly (928-936). Paris: ICOMOS. Available in: http:// openarchive.icomos.org/1307/1/IV-3-Article6_Greffe.pdf

HERTZOG, A. (2011). Les géographes et le patrimoine. EchoGéo [En ligne], 18, mis en ligne le 05 décembre 2011, consulté le 19 juillet 2019. https://doi. org/10.4000/echogeo. 12840

JACQUOT, S.; CHAREYRON, G. et COUSIN, S. (2018). Le tourisme de mémoire au prisme du «big data». Cartographier les circulations touristiques pour observer les pratiques mémorielles, Mondes du Tourisme [En ligne], 14, mis en ligne le 30 juin 2018, consulté le 22 juillet 2019. https://doi.org/10.4000/tourisme.1713 JANSEN-VERBEKE, M; GEORGE, W. (2015). Les paysages mémoriels de la Grande Guerre (1914-1918): un changement de paradigme dans la recherche sur le 
tourisme de mémoire, Via [En ligne], 8, mis en ligne le 01 novembre 2015, consulté le 23 juillet 2019. https://doi.org/10.4000/viatourism.485

Jornal-Reclamo da Mais Linda Praia de Portugal (1940-1941).

JÚNIOR, J. C. (1998). Ericeira 50 Anos Depois... Os refugiados estrangeiros da 2. ${ }^{a}$ Guerra Mundial. 3. ${ }^{a}$ edição. Ericeira: Mar das Letras.

Liberation Route Europe Foundation. Available in: https://liberationroute.com/ pages/liberation-route-europe-foundation.

LIMA, M. J.; NEVES, J. S. (2005). Cascais e a 'memória dos exílios'. Cascais: Câmara Municipal de Cascais.

KNAFOU, R. (2012). Auschwitz, lieu touristique? Via [En línea], 1, Publicado el 16 marzo 2012, consultado el 19 julio 2019. https://doi.org/10.4000/ viatourism. 1593

MAIA, S. V.; BAPTISTA, M. M. (2011). As rotas como estratégia turística: percepção de benefícios e obstáculos na constituição de rotas museológicas na região de Aveiro. Tourism \& Management Studies, $n .^{\circ}$ extraordinário 1, 672-682. Available in: https://www.researchgate.net/publication/277074299_AS_ROTAS_ COMO_ESTRATEGIA_TURISTICA_PERCEPCAO_DE_BENEFICIOS_E_ OBSTACULOS_NA_CONSTITUICAO_DE_ROTAS_MUSEOLOGICAS_NA_ REGIAO_DE_AVEIRO

MALCUZYNSKI, W. (sf). Available in: http://old.sousamendesfoundation.org/ malcuzynski/.

MILGRAM, A. (2010). Portugal, Salazar e os judeus. Lisboa: Gradiva.

MÜHLEN, P. (2012), Caminhos de fuga Espanha-Portugal. A migração alemã e o êxodo para fora da Europa de 1933 a 1945. Coimbra: IUC.

NADAL FERRERAS, Rafael (2019). El hijo del italiano. Barcelona: Planeta.

NORA, Pierre (1999). Les lieux de mémoire. In J.C. RUANO-BORBALAN (coord.). L'Histoire aujourd'hui. Nouveaux objets de recherche. Courants et débats. Le métier d'historien (343-348). Paris: Éditions Sciences Humaines

ORDÓNEZ, Rafael (sf). Amor y cuernos: la historia de los refugiados italianos em Girona que huyeron de Hitler. Available in: https://www.elindependiente.com/ tendencias/historia/2019/05/24/amor-y-cuernos-la-historia-de-los-refugiadositalianos-en-girona-que-huyeron-de-hitler/

Out of Hitler's Reach (sf). Available in: https://www.iowapbs.org/iowapathways/ artifact/out-hitler's-reach; https://www.thegazette.com/news/80-years-agoscattergood-took-in-refugees-fleeing-nazis/

PEREIRA, C. H. (2017). Refugiados da Segunda Guerra Mundial nas Caldas da Rainha (1940-1946). Lisboa: Edições Colibri.

PIMENTEL, I. F. (1996). Refugiados. In F. DE ROSAS e J.M.B. BRITO (dirs.). Dicionário de história do Estado Novo. Vol. II: M-Z (823-825). Venda Nova: Bertrand Editora. 
PIMENTEL, I. F. (2006). Judeus em Portugal durante a I Grande Guerra. Em fuga de Hitler e do Holocausto. Lisboa: A Esfera dos Livros.

RAMALHO, M. M. (2014). Vilar Formoso Fronteira da Paz, Almeida: Câmara Municipal de Almeida.

Randonneurs de mémoire. Available in: https://www.visitluxembourg.com/fr/toursrecommandes/tour/t/randonneurs-de-memoire

RICOEUR, Paul (2000). La mémoire, l'histoire, l'oubli. Paris: Éditions du Seuil.

Rota Arte Nova Pelas Ruas do Bairro Novo. Figueira da Foz (s. d.). Figueira da Foz: Escola Secundária Dr. Joaquim de Carvalho.

Sousa Mendes Foundation. Available in: http://sousamendesfoundation.org.

TELO, A. J. (2001). Portugal e a II Guerra Mundial. In Roberto CARNEIRO and A.T. MATOS, (coords.). Memória de Portugal. O milénio português (504-505). Lisboa: Círculo de Leitores.

Tilllinger. Available in: http://sousamendesfoundation.org/tillinger/

VAQUINHAS, I. (2015). Huyendo de la guerra civil: los refugiados españoles en Figueira da Foz (1936-1939). In Pensar con la historia desde el siglo XXI. Actas del XII Congreso de la Asociación de Historia Contemporánea (4757-4778). Madrid: Uma Ediciones. Available in: https://dialnet.unirioja.es/servlet/ articulo? codigo $=5117163$.

VAQUINHAS, I. (2013). O Casino da Figueira. Sua evolução histórica desde o TeatroCirco à actualidade (1884-1978). 2. ${ }^{a}$ edição. Coimbra: Palimage.

VAQUINHAS, I. (2011). Apontamentos para a história do Teatro-Circo Saraiva de Carvalho da Figueira da Foz (1884-1895). Arquipélago. História. 2. a série. XIV-XV, 115-141. Available in: http://hdl.handle.net/10316/33457

VIQUEIRA, M. (1994). Praiabela. Venda Nova: Bertrand Editora.

Visite historique à Vincennes: parcours autor de la seconde guerre mondiale. Available in: https://exploreparis.com/fr/1128-visite-historique-vincennes-parcours-autour-seconde-guerre-mondiale.html.

A Voz da Figueira, 7 de Dezembro de 1972. 